\title{
"The effect of leadership and organizational culture on employee performance that is educated by motivation (study on the implementation empowerment programs in Jayapura city)"
}

\begin{tabular}{|c|c|}
\hline AUTHORS & $\begin{array}{l}\text { Nansi Lidya Lolowang } \\
\text { Eka Afnan Troena } \\
\text { Atim Djazuli (D https://orcid.org/0000-0003-4458-4880 } \\
\text { Siti Aisjah (D https://orcid.org/0000-0003-0054-9004 }\end{array}$ \\
\hline ARTICLE INFO & $\begin{array}{l}\text { Nansi Lidya Lolowang, Eka Afnan Troena, Atim Djazuli and Siti Aisjah (2019). } \\
\text { The effect of leadership and organizational culture on employee performance that } \\
\text { is educated by motivation (study on the implementation empowerment programs } \\
\text { in Jayapura city). Problems and Perspectives in Management, 17(1), 268-277. } \\
\text { doi:10.21511/ppm.17(1).2019.23 }\end{array}$ \\
\hline DOI & http://dx.doi.org/10.21511/ppm.17(1).2019.23 \\
\hline RELEASED ON & Wednesday, 20 March 2019 \\
\hline RECEIVED ON & Saturday, 08 December 2018 \\
\hline \multirow[t]{2}{*}{ ACCEPTED ON } & Friday, 01 March 2019 \\
\hline & $(\mathrm{sc}) \mathbf{E Y}$ \\
\hline LICENSE & $\begin{array}{l}\text { This work is licensed under a Creative Commons Attribution } 4.0 \text { International } \\
\text { License }\end{array}$ \\
\hline JOURNAL & "Problems and Perspectives in Management" \\
\hline ISSN PRINT & $1727-7051$ \\
\hline ISSN ONLINE & $1810-5467$ \\
\hline PUBLISHER & LLC "Consulting Publishing Company "Business Perspectives" \\
\hline FOUNDER & LLC "Consulting Publishing Company "Business Perspectives" \\
\hline
\end{tabular}

NUMBER OF REFERENCES

22
NUMBER OF FIGURES

1
NUMBER OF TABLES

0

(C) The author(s) 2023. This publication is an open access article. 


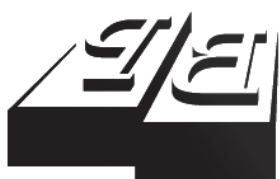

BUSINESS PERSPECTIVES

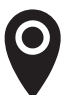

LLC "CPC "Business Perspectives" Hryhorii Skovoroda lane, 10, Sumy, 40022, Ukraine

www.businessperspectives.org

Received on: $8^{\text {th }}$ of December, 2018 Accepted on: $1^{\text {st }}$ of March, 2019

(C) Nansi Lidya Lolowang

Eka Afnan Troena, Atim Djazuli, Siti Aisjah, 2019

Nansi Lidya Lolowang, Student, Program Doctor of Management science, University of Brawijaya, Indonesia.

Eka Afnan Troena, Professor, Lecturer Faculty of Economics and Business, University of Brawijaya, Indonesia.

Atim Djazuli, Doctor, Lecturer Faculty of Economics and Business, University of Brawijaya, Indonesia.

Siti Aisjah, Doctor, Lecture

Faculty of Economics and Business, University of Brawijaya, Indonesia.

\section{(c) (i)}

This is an Open Access article, distributed under the terms of the Creative Commons Attribution 4.0 International license, which permits unrestricted re-use, distribution, and reproduction in any medium, provided the original work is properly cited.

Nansi Lidya Lolowang (Indonesia), Eka Afnan Troena (Indonesia),

Atim Djazuli (Indonesia), Siti Aisjah (Indonesia)

\title{
THE EFFECT OF LEADERSHIP AND ORGANIZATIONAL CULTURE ON EMPLOYEE PERFORMANCE THAT IS EDUCATED BY MOTIVATION (STUDY ON THE IMPLEMENTATION EMPOWERMENT PROGRAMS IN JAYAPURA CITY)
}

\begin{abstract}
Villages and sub-districts in Jayapura city are public organizations that provide service to the community. Villages and urban organizations require leadership, organizational culture and strong work motivation to support performance improvement. This research was conducted in 39 villages and sub-districts in the city of Jayapura. The population of this study was permanent employees in the villages and sub-districts in the city of Jayapura, which numbered 96 employees. All populations were chosen as research respondents, this research was census research. The analytical tool used in the research is Partial Least Square (PLS). The results of the study show that, first, direct leadership has no significant effect on employee performance, second, organizational culture has a significant effect on employee performance, third, leadership has a significant effect on work motivation, fourth, organizational culture has a significant effect on work motivation, fifth, work motivation has a significant effect on employee performance, sixth, work motivation is a perfect mediator of the influence of leadership on employee performance, seventh, work motivation as a partial mediator of the influence of organizational culture on employee performance.
\end{abstract}

\section{Keywords}

\section{JEL Classification $\quad$ R58}

\section{INTRODUCTION}

Since 2004, Indonesian government has introduced regional autonomy that confers regional governments' authority to govern their own jurisdictions. It passed on No. 32 Act of 2004 on regional autonomy that ensures regional governments' authority to run their governance independently. The purposes of this policy are the achievement of optimum effectiveness and efficiency and regional government's familiarity of their local needs, potential and norms for the ways to materialize it.

The discussion on the purposes of regional autonomy becomes interesting when regional governments which are the subjects of autonomy policy are too ill-equipped to continue the task of self-governing. Indonesia has many regional governments with such conditions. Jayapura is one case among others, and provides the challenge for implementation of autonomy policy at national scale. Such conditions could range from low human resources that regional governments have instead of their instrumental position for optimal service deliv- 
ery to society, culture that acknowledges the higher position of cultural leaders than organizational leaders in such extent that can make policy implementation become more complex than it should be, cultural social strata arrangement where a leader in government organization happens to be in a low caste in society and otherwise that can make policy get blocked. All these issues exist in Jayapura, not to mention its common landscape of society, which is surrounded by villages. The result is that in Jayapura, it is common to find village governments that run administration at village level.

The failing poverty alleviation program in Jayapura as reflected from its fluctuating rates between 2010 and 2013 explains this situation. The poverty rate reached its peak in 2010 with $17.31 \%$, and in 2011 and 2012 it decreased to $15.77 \%$. Surprisingly, it raises again to $16.19 \%$ in 2013 . Many considered that all issues mentioned above interfered the policy implementation in the field.

The present study explores the role of leadership in Jayapura village governments. Several researches have proven causal relationship between leadership and employees' performance (Sharkie, 2009; Cools, 2010; Salman, 2011; Cheng-Kang \& Chuan-Yin, 2011; Xiao-Dhong et al., 2013), confirming the significant effect of leadership on the increase in employees' performance, including leaders' expected competence, high integrity, and obvious vision that give a clear direction to where achievements should be made. However, other researches prove otherwise. Ha and Nguyen (2014), for example, revealed that leadership alone could not increase employees' performance, so did Yang et al. (2012) that emphasized on work satisfaction as a mediator in the relationship between leadership and employees' performance. This inconsistence in research results is worth further research, especially in governments with several handicaps in autonomy era.

Beside leadership, organizational culture has a prominent role in increasing employees' performance. Culture that supports conducive work atmosphere, commitment and discipline is the instrument for increased employees' performance.

\section{REVIEW OF THE RELATED LITERATURE}

Leadership refers to the use of authority without any coercion (noncoercive) to achieve certain visions and missions of an organization, to motivate the members of the organization to move in harmony in achieving the goals and to help defining and creating favorable organizational culture (Griffin, 2004). Leadership is seen as the ability to persuade and handle other persons to achive maximum result with less friction and hard work, and leadership is also the creative and planned strength, spirit and morality (De Hoogh, 2008).

Hersey and Blanchard (2005) created the situational theory and conducted an approach focusing on bigger attention to the characteristics of employees in determining the appropriate leadership manners. This theory explains that it is necessary for managers to adjust their manners and behaviors regarding to the various characteristics of the employees in order to fit the expectations of the employees, gain new experience, improve the expertise and capability in holding up the responsibility as leaders.

Motivation is a process that explains the strength, direction and exertion of a person in achieving certain goal (Robbins \& Judge, 2013). Motivation as the driving force refers to the natural drive of the people to manage their lives in such ways that they gain satisfaction (Clayton, 2002). Motivation is also a set of mannners, which are the fundamental guidances for a person to act and behave in such ways to achieve certain specific goals (Soeroso, 2002). Based on those definitions stated by some experts, it can be inferred that motivation is a personal drive that leads someone to act and behave in certain ways to satisfy herself/himself and to live a life, which is directed in certain point to achieve certain goals. According to Robbins and Judge (2013), motivation is also a process to explain the strength, direction and exertion of a person to achive certain goals, which is generally related to the attempts made to achieve the goal.

Meanwhile, organizational culture was defined by Luthan (1998) as a set of norms and values used to 
direct and manage the members of an organization. Each member of the organization is expected to act and behave in accordance to the organizational culture that applies in the organization to be accepted by the other members. Mangkunegara (2005) stated that organizational culture is a set of assumptions or a set of beliefs, values and norms, which are nurtured in an organization and which are used by the members of the organization as the guideline of behavior and as the guidance to solve problems related to external adaptation and internal integration. Whilst, Hofstede (2001, p. 9) defined organizational culture as the "the collective programming of the mind that distinguishes the members of one group or category of people from another". According to this definition, organizational culture is the modification of thoughts (thinking), feeling and acting as the consequences of holding certain belief, behavior and skills, which distinguish the members of certain organization from the members of other organizations. From the view, it can be understood that organizational culture is a set of values and norms, which are applied as a guideline in determining certain belief, behaviors, and skills for the members of an organization in performing their work.

Etty Indriani and Hari Waluyo (2012) have conducted a study on the effect of leadership and organizational culture on employees' performance through organizational commitment as the intervening variable. The result of their study showed that the leadership has a positive and significant effect on employees' performance and leadership also has a more direct and dominant effect on employees' performance compared to the effect of the organizational commitment as the intervening variable on employees' performance. Charlson (2002) conducted a study on the investigation of the correlation between organizational culture and employees' performance, the results of which showed that there is a positive and significant correlation between organizational culture and employees' performance.

There have been a continuum number of studies done on the investigation of the causal relationship between leadership and employees' performance such as the ones conducted by Sharkie (2009), Cools (2010), Salman (2011), Cheng-Kang and Chuan-Yin (2011), Xiao-Dhong et al. (2013), the results of which indicated the existence of positive and significant effect of leadership on the improvement of employees' performance. Based on the result of those studies, employees' performance will be improved when the leaders have certain compentences as expected by the employees, possess high integrity and managerial capability that can be accepted and appreciated by any individual in the organization.

This study investigated the effect of leadership toward employees' performance through employees' motivation to work as the mediating variable done to several organizations. Out of 187 responses which had been received by the researchers, 118 responses were used as the data of this study to be analyzed. Employees' performance which was illustrated as the performance of every person in charge who was responsible to run certain project showed that leadership had an effect on the improvement of employees' performance through the role of motivation as the mediating variable (Li et al., 2012; Cools, 2010).

\subsection{Theoretical framework of the study}

This conceptual theoretical framework explains the relationship among the variables of this study. The relationship among the variables of this study has been constructed upon the theory of leadership, theory of organizational cuture, theory of motivation and results of previous studies on the investigation of the relationship between the leadership, motivation on employees' performance. Regarding to the relationship among the variables of this study as proposed by the existing theories and previous studies, the conceptual framework of this study was constructed as follows.

\subsection{Hypotheses of the study}

The results of studies conducted by Sharkie (2009), Cools (2010), Salman (2011) showed that there were positive and significant effects of leadership on the improvement of employees' performance in which employees' performance will be improved when the leader possesses capabilities that meet the expectation of the employees, own high integrity and has adequate managerial skills, which can be accepted and appreciated by each individual and all members of the organization. On the other hand, the result of a study conducted by $\mathrm{Ha}$ and Nguyen (2014) showed that the leadership was not able to improve employees' performance, since it 


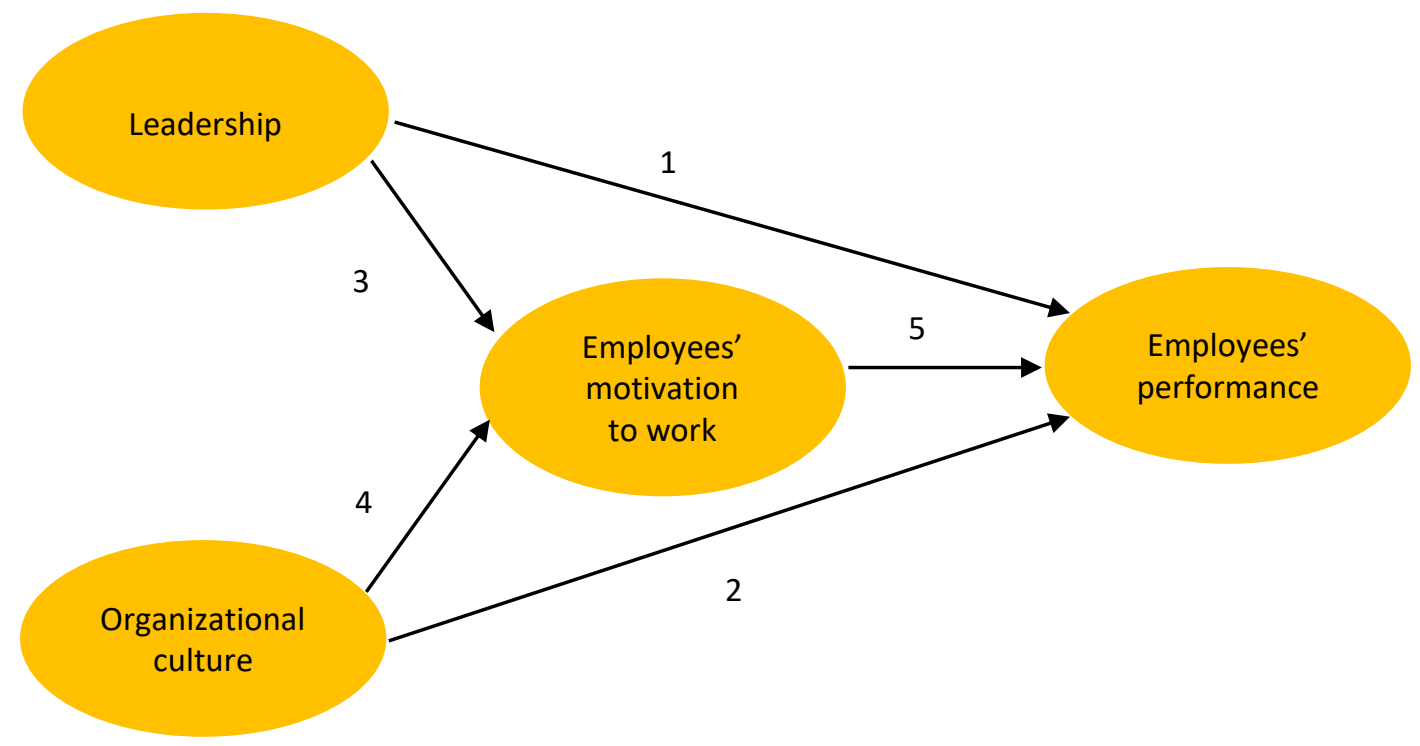

Figure 1. Conceptual framework

had to be mediated by the job satisfaction as the mediating variable (Yang et al., 2012). Therefore, in this study, this research gap was formulated into the first hypothesis as follows:

\section{H1: Leadership has certain effects on employees' performance.}

Good organizational culture supports the creation of favorable and conducive work atmosphere, enhances the work commitments and improves the discipline in performing the work which appears to be the basic necessities and expectations of the members of an organization. There has been a number of studies, which have confirmed the existence of positive and significant effect of organizational culture, in which the results showed that the better the quality of the organizational culture, the higher the quality of employees' performance (Gajendran \& Brewer, 2007; Yunus, 2010; Haerani et al., 2012; Cools, 2010; Oemar, 2007). Yet, contradictive results were found by Liem (1995) and in which they found that the organizational culture decreases employees' peferformance. Hence, the second hypothesis of this study was formulated as follows:

H2: Organizational culture has an effect on employees' performance.

Research done by Li et al. (2012), Ahmad (2009), Valensi (2008) investigated the effect of leader- ship on employees' motivation, the result of which showed a positive and significant relationship between the leadership characteristics and employees' motivation to work. Similar results were also found by Cools (2010), Chaudhry et al. (2012) who found the positive and significant effect of transformational and transactional leadership on employees' motivation to work in Pakistan. Thus, the third hypothesis of this study was developed as follows:

\section{H3: Leadership has an effect to employees' moti- vation to work.}

Positive values nurtured in an organization will construct good organizational culture, which will be able to drive and motivate the employees, especially the employees of village offices to always stay motivated in doing their work in order to achieve the goals of the organization as agreed beforehand. The result of several researches done by Valensi (2008), Cools (2010), Cucu-Ciuhan and Guita-Alexandru (2014) showed positive and significant correlation proving that the better the organizational culture, the stronger it is in enhancing employees' motivation to work. Similar result was confirmed by Panagoitis et al. (2014) who conducted the research in a state-owned university in Athena where they found that organizational culture which applies the system of clan were able to improve employees' motivation. However, 
when organizations apply the system of hierarchy / bureaucracy, employees' motivation to work was likely to decrease. The fourth hypothesis of this study was formulated as follows:

\section{H4: Organizational culture increases employees' motivation to work.}

According to Clayton (2002), motivation refers to the driving force, which appears to be a natural drive that gives the feeling of satisfaction for employees in their life. Motivation is constructed by employees' attitude in facing any situation in the workplace. Motivation is also a condition or an energy that drives the employees to act and behave in certain ways to achieve the organizational goals.

Soeroso (2002) defined motivation as a set of behaviors, which becomes the guideline for members of an organization to act and behave in certain ways to achieve the specific goal. Employees' motivation to work might appear in two different basic classifications, which are: 1) extrinsic motivation (motivation from outside) and 2) intrinsic motivation (motivation from inside).

Regarding those views, it is apparent that the main goal in improving employees' motivation to work is to grow employees' willingness to work and behave in certain ways that will improve their performance. The fifth hypothesis of this study was formulated as follows:

H5: Employees' motivation has an effect on employees' performance.

This study aimed at investigating the effect of leadership on employees' performance through employees' motivation to work which was done in some companies. Out of the total of 187 responses obtained in the data collection process, there were 118 responses, which were used as the research data to analyze. Employees' performance was reflected by the performance of each person in charge of every project. The result of the data analysis showed that leadership had an effect on the improvement of employees' performance through the role of employees' motivation to work as the mediating variable ( $\mathrm{Li}, \mathrm{Tan}, \& \mathrm{Teo}, 2012$; Cools, 2010). Thus, the sixth research hypothesis of this study was formulated as follows.
H6: Employees' motivation to work has a role in mediating the effect of leadership on employees' performance.

Another research has investigated the effect of organizational culture on employees' performance through the role of employees' motivation as the mediating variable (Cools, 2010). The result of the study showed that there was found a certain role of employees' motivation as the mediating variable in the effect of leadership on employees' performance. Therefore, the seventh hypothesis of this study was formulated as follows:

H7: Employees' motivation to work has a role on the effect of organizational culture toward employees' performance as the mediating variable.

\subsection{Operational keywords definition}

\subsubsection{Leadership (X1)}

Leadership is that the use of authority while not coerción (non-coercieve) so as to form bound objectives or goups encourages the member of the cluster to attain those objectives and outline the group culture or organizational culture. Indicators of the leadership as the variable of this study refer to the ones proposed by Drucker (1996), McShane and VinGlinov (2008), Hayati and Caniago (2012), Yang et al. (2011), including three domains of mastery, which are the personal mastery, leadership mastery and organizational mastery.

\subsubsection{Organizational culture $\left(X_{2}\right)$}

Organizational culture is defined as anything that should be done within an organization or companies including the treatments for the employees and other operational activities of the organization. To measure the organizational culture, the researchers used the four-dimension measurement as proposed by Denison and Mishra (1992), including:

A) involvement: an effective organization is the one that empowers and develop its resources in any level;

B) consistency: it emphasizes on the strong positive effect of culture on the effectiveness of an organization; 
C) adaptability: it refers to the explanation on the system of norms and beliefs which support the capacity of an organization to be able to accept, interpret, and translate any signs from the surroundings in order to become more sensitive in capturing any changes of internal behaviors to keep living, growing and developing;

D) mission: it refers to the awareness on certain mission that will direct the organization to certain clear direction and target in order to be able to define and construct plan and appropriate actions to do.

\subsubsection{Motivation (Y1)}

The theory of motivation according to Vroom (1964) about the cognitive theory of motivation explaining the reasons why people would not do anything that they think they cannot do it even when they are interested in the reward for the job. The indicators of the variable motivation used in this study refer to the ones proposed by Vroom, which are expectation, instrumentality, and valency.

\subsubsection{Employees' performance (Y2)}

Employees' performance refers to the employees' achievement in doing her/his work, which supports the success of the company in achieving the organizational goals (Sutrisno, 2010). The indicators used in this study were adapted from the framework proposed by Mc Nesse (2009), including:
A) quantity and quality of the work;
B) persistence and work durability;
C) discipline/presence;
D) teamwork;
E) awareness on work safety;
F) responsibility of the work;
G) initiative.

\section{RESEARCH METHOD}

This study was conducted in 39 village offices in five districts of Jayapura city under the governance of Jayapura city, including: 1) the district of North Jayapura, 2) the district of South
Jayapura, 3) the district of Abepura, 4) the district of Heram and 5) the district of Muara Tami. The researchers had adequate knowledge about that location, which allowed them to access the information easily. This study involved participations from all of the employees of village offices in Jayapura city as the executor of the village empowerment program in Jayapura. The study was conducted from January 2015 till March 2015. The data analysis technique used in this study was the Partial Least Square (PLS) using an application called SmartPLS 2.0 M3. (Ghozali, 2011a, p. 18). The data obtained in this study were analyzed using quantitative data analysis approach.

\section{RESULTS AND DISCUSSIONS}

The result of the analysis on the direct path coefficient of the leadership to employees' performance showed value of -0.028 and $p$-value at 0.745 . The obtained $p$-value which is greater than 0.05 shows that the leadership does not have any significant effect on employees' performance. Based on the result of the data analysis, the hypothesis 1 stating that the higher the leadership value improves employees' performance is rejected.

\section{H1: Higher value of leadership improves employ- ees'performance.}

The result of the analysis on the direct path coefficient of the organizational culture to employees' performance showed value of -0.748 and $p$-value at 0.000 . The obtained $p$-value which is lesser than 0.05 shows that the organizational culture has a significant effect on employees' performance. Based on those result, the hypothesis 2 stating that better organizational culture improves employees' performance is accepted.

H2: Better organizational culture improves employees' performance.

The result of the analysis on the direct path coefficient of the leadership to employees' motivation to work showed value of 0.304 and $p$-value at 0.001 . The obtained $p$-value which is lesser than 0.05 shows that leadership has a significant effect 
on employees' motivation to work. Based on those result, the hypothesis 3 stating that better leadership improves employees' motivation to work is accepted.

\section{H3: Higher the value of leadership improves the employees' motivation to work.}

The result of the analysis on the direct path coefficient of the organizational culture to employees' motivation to work showed value of 0.424 and $p$-value at 0.000 . The obtained $p$-value which is lesser than 0.05 shows that the organizational culture has a significant effect on employees' motivation to work. Based on those result, the hypothesis 4 stating that better organizational culture improves employees' motivation to work is accepted.

H4: Better organizational culture improves employees' motivation to work.

The result of the analysis on the direct path coefficient of employees motivation to work to employees' performance showed value of 0.284 and $p$-value at 0.002 . The obtained $p$-value which is lesser than 0.05 shows that employees' motivation to work has a significant effect on employees' performance. Based on those result, the hypothesis 5 stating that stronger employees' motivation to work improves employees' performance is accepted.

H5: Stronger employees' motivation to work improves employees' performance.

The result of the Sobel analysis on the indirect path coefficient of the leadership to employees' performance through employees' motivation as the mediating variable showed value of significance at 0.021 . The obtained Sobel value which is lesser than 0.05 shows that employees' motivation has a role as mediating variable on the effect of leadership on employees' performance. Based on those result, the hypothesis 6 stating that the improvement of leadership improves employees' performance through employees' motivation as the mediating variable is accepted.

H6: Higher value of leadership improves employees' performance through employees' motivation as the mediating variable.
The result of the Sobel analysis on the indirect path coefficient of the organizational culture to employees' performance through employees' motivation as the mediating variable showed value of significance at 0.009 . The obtained Sobel value which is lesser than 0.05 shows that employees' motivation has a role as mediating variable on the effect of organizational culture on employees' performance. Based on those result, the hypothesis 7 stating that the improvement of organizational culture improves employees' performance through employees' motivation as the mediating variable is accepted.

H7: Better organizational culture improves employees' performance through employees' motivation as the mediating variable.

The leadership applied by a leader is able to drive employees to grow higher motivation in doing their work. High motivation to work will direct the employees to do the job well, which will also improve their performance. Improving employees' motivation to work is the orientation that should be put into the priority of the leaders in managing the organizations or companies. Leaders should be able to improve strong employees' motivation, which will also improve employees' performance. Leadership applied in village offices in Jayapura was still considered not yet optimally done, which can be seen from the average value of leadership at 3.81. The obtained value shows that the leaders of the offices do not have appropriate organizational compentence yet. The least point of the leadership was the organizational competence which was found at an average value of 3.72 or $7.29 \%$. The existence of the answer 2 (disagree) and (2) (strongly disagree) indicates that leaders of the offices were considered not yet capable in showing their organizational competence. The leaders of village offices in Jayapura were considered incapable in persuading and directing their employees to do their work optimally as good employees.

The results of this study do not support the view of House (1971) who stated that the leadership is able to improve employees' performance. On the other hand, the results of this study support the view of Yang et al. (2012) that leadership does not have any effect on employees' performance. The result the 
study conducted by Yang et al. (2012) showed that the leadership style applied by a leader does not affect employees' performance.

Motivation within someone's self will direct the person to voluntarily improve her/his attempts to achieve the organizational goals (Robbins, 1996). The view proposed by George and Jones (2002) and Robbins (1996) showed that one's motivation is able to improve the performance. According to Schein (1997), Robbins (2001), George and Jones (2002), employees' motivation to work is a mediating variable of the effect of leadership on employees' performance. The test to investigate this indirect effect of leadership on employees' performance through employees' motivation was done using the Sobel test. The result of the Sobel test shows level of significance of the indirect effects among the variable at the value of 0.021 . This result shows that employees' motivation to work appears as the mediating variable of the effect of leadership on employees' performance. Since the leadership does not have direct effect on employees' performance, then employees' motivation appears to be the total mediating variable to the effect of leadership on employees' performance. Therefore, leadership does not directly affect employees' performance, instead it is able to streghten employees' motivation to work, which gives positive effect toward their performance.

The results of this study support the theory of leadership proposed by Barbuto (2005) that leadership does not directly produce good performance, yet it is able to grow individual's motivation to improve the performance. There have been a number of previous studies stating that employees' motivation to work mediates the effect of leadership on employees' performance. The results of this study add up to the results of the previous studies done by Li et al. (2012), Ahmad (2009), Valensi (2008), Arthur (2003), Hayati and Caniago (2012), Cools (2010), whose results showed that employees' motivation is the mediating variable of the effect of leadership on employees' performance.

The most frequently shown indicator of organizational culture by the village offices in Jayapura was the mission. Mission of the organization had a clear direction, which could be simply implemented by the employees. All of this time, the employees actually have adequate undestanding that the goal of the organization is to provide services for the so- ciety through the village empowerment program. Employees had enough knowledge on the village empowerment program, which allowed them to implement the program well. Besides, their good knowledge on the orientations and the goals of the organization has grown stronger drive and motivation to do their work well. The results of this study also support the theory of organizational culture stated by Robbins and Judge (2007) that strong organizational culture results in good employees' performance and job satisfaction. In addition, the results of this study showed that organizational culture applied in village offices in Jayapura has been able to improve employees' performance. The implementation of the concept of organizational culture as stated by Denison (1990) consists of some aspects, which are: involvement, consistency, adaptability and mission which are able to drive better employees' performance. The use of diferent types of leadership resulted to similar research findings. The results of this study gave theoretical supports for the theory of leadership proposed by Robbins and Judge (2007). The results of this study also support the research findings of Gajendran and Brewer (2007), Yunus (2010), Haerani et al. (2012), and Oemar (2007). There have been a number of previous studies, which conducted studies on the issues of business-related organization. Meanwhile, this study investigated issues that happended in public organization which is the village offices. Besides, the concept of organizational culture in this study is different from the one used in other studies. Although there were some differences in the determination of the subject of the studies and the organizational culture, the results were similar. The result of this study showed that the concept of organizational culture proposed by Denison (1990) is applicable to implement in public organizations. The results of this study also give theoretical supports to the theory of organizational culture proposed by Robbins and Judge (2007). Besides, this study also streghen the reseach findings of Gajendran and Brewer (2007), Yunus (2010), Haerani et al. (2012), and Oemar (2007). This shows that the results of this study are able to give theoretical, as well as practical contribution to the improvement of employees' performance.

\subsection{Limitations of the study}

This study was conducted in village offices in Jayapura city, which were considered as public 
organizations. The subjects of this study had different characteristics from village offices in other areas in Papua. Therefore, the results of this study cannot be simply generated to represent similar issues, which happen in other regencies in Papua Province.

\section{CONCLUSION}

Leadership has an important role in the organization so that individuals do activities as expected by the organization. In this study, the leadership in villages and urban villages in the city of Jayapura was not directly able to have an impact on employee performance. Nevertheless, leadership in villages and urban villages in the city of Jayapura was able to provide encouragement to employees to increase motivation.

Strong organizational culture is indicated by the behavior of organizational members in carrying out work that supports organizational goals. The organizational culture of the villages and sub-districts in the city of Jayapura is able to have a direct impact on employee performance. In addition, the organizational culture of villages and sub-districts in the city of Jayapura is able to increase employee motivation.

Motivation of employees in villages and urban villages in the city of Jayapura is still not at a high level. Employee motivation that still needs to be improved is valence. In order to fulfill the valence of village and sub-districts employees in the city of Jayapura, the Jayapura city government provided an opportunity to employees who had good performance at the village and sub-districts level in the city of Jayapura to be promoted to the city level government. In addition, leaders at the village and sub-districts level in the city of Jayapura can provide jobs that are in accordance with the capabilities possessed by employees so that employees have the opportunity to channel their abilities in running jobs. The opportunity to get better job opportunities and the opportunity to channel their abilities can increase employee motivation.

Employee performance is the output produced by employees in carrying out work. Employee performance that is most felt by employees so far is tenacity and endurance, where villages and urban villages in the city of Jayapura are the providers of service to the community. Many kinds of problems related to the community are widely accepted by organizations at the village and sub-districts level, so that existing employees are required to have good service to the community. In addition, employees are also required to have responsibility in carrying out their work, their responsibilities make workers willing to carry out work in accordance with their functions and duties.

\section{REFERENCES}

1. Clayton, Y. (2002). Motivation, Existence, relatedness, and growth: Human needs in organizational settings. New York: The Free Press.

2. Cools, K. (2010). The leadership effects of performance measuring and culture organisation compensation on motivation: degree associate empirical study de economic (303 p.).

3. Cucu-Ciuhan \& Guita-Alexandru (2014). Organizational cultures versus work motivation for the academic staff in a public university. Procedia Social and Behavioral
Sciences, 127, 448-453. Retrieved from www.sciencedirect.com

4. Denison, D. R. (1990). Corporate Culture and Organizational Effectiveness. New York, NY: John Wiley \& Sons.

5. Drucker, P. F. (1996). The Leader of The Future. New York: The Drucker Fondation.

6. Griffin, Ricky W. (2004). Manajemen (7th ed.). Jakarta: Alih Bahasa, Penerbit Erlangga.

7. Ha, M. N., \& Nguyen, T. V. H. (2014). The Influence of Leadership behaviors on Employee
Performance in the Context of Software Companies in Vietnam. Advances in Management \& Applied Economics, 4(3), 157-171. Retrieved from https://ideas.repec.org/a/spt/ admaec/v4y2014i3f4_3_11.html

8. Hayati, K., \& Caniago, I. (2012). Islamic work ethic: The Role of Intrinsic Motivation, Job Satisfaction, Organizational Commitment and Job Performance. Procedia, Social and Behavioral Science, 65, 272277. https://doi.org/10.1016/j. sbspro.2012.11.122 
9. Hersey, P., \& Blanchard, K. (2005). Center for Leadership Studies 1. Joernal Psicologi Social, 10, 271-301.

10. Hofstede, G. (2001). Culture's Consequences: Comparing VA and Behaviors. Institutions, and Organizations across Nations. Thousand Oaks: Sage Publications.

11. Indriyani, Etty dan Waluyo, Hari (2012). Pengaruh Kepemimpinan Dan Budaya Organisasi Terhadap Kinerja Pegawai Negeri Sipil di Sekretariat Daerah Kabupaten Karanganyar Dengan Komitmen Organisasi Sebagai Varia bel Intervening. Jurnal STIE-AUB, Sura karta.

12. Li, Y., Tan, C., \& Teo, H.-H. (2012) Leadership characteristic and developers, motivation in open source software development. Information \& Management, 49(5), 257-267. https://doi.org/10.1016/j. im.2012.05.005

13. McShane, S. L., \& Von Glinow, M. A. (2000). Organizational
Behavior. Irwin/McGraw-Hill. Burr Ridge, IL.

14. Panagiotis, M., Alexandros, S., \& George, P. (2014). Organizational Culture and Motivation in the Public Sector. The Case of the City of Zografou. Procedia Economics and Finance, 14, 415-424. https://doi.org/10.1016/ s2212-5671(14)00730-8

15. Robbins, St. (2001). Basic Motivation Concepts. In Organizational Behavior (pp. 155209). Prentice Hall, New Jersey.

16. Salman, Z. (2011). Leadership Styles and Employee Performance (A case Study of Shakarganj Mills Limited Jhang Pakistan). Interdisciplinary of Contemporary Research in Business, 3(6).

17. Scehneider, B. (2005). Employee organization culture linkages (78 p.). New York Journal Research.

18. Schein, E. (2002). Organizational Culture and Leadership (2nd ed.). San Fransisco: Jossey-Bass Publishers.

19. Shamir, B., House, R. J., \& Arthur, M. B. (2008). The Motivational Effects of Charismatic Leadership: A Self-Concept Based Theory. Organization Science, 4(4), 577-594. https://doi.org/10.1287/orsc.4.4.577

20. Sharkie, R. (2009). Trust in Leadership is vital for Employee Performance. Management Research News, 32(5), 491-498. https://doi. org/10.1108/01409170910952985

21. Tan (2002). Guide for Management. Changing Your Corparate Culture. Journal of Creative Behavior, 42, 33-41.

22. Yang, L. R., Yen, H. F., \& Chiang, Y. F. (2012). A framework for assessing impacts of leadership ability on police project performance: Mediating role of job satisfaction and tempering role of project kind. Policing, 35(3), 528-550. https://doi. org/10.1108/13639511211250785 